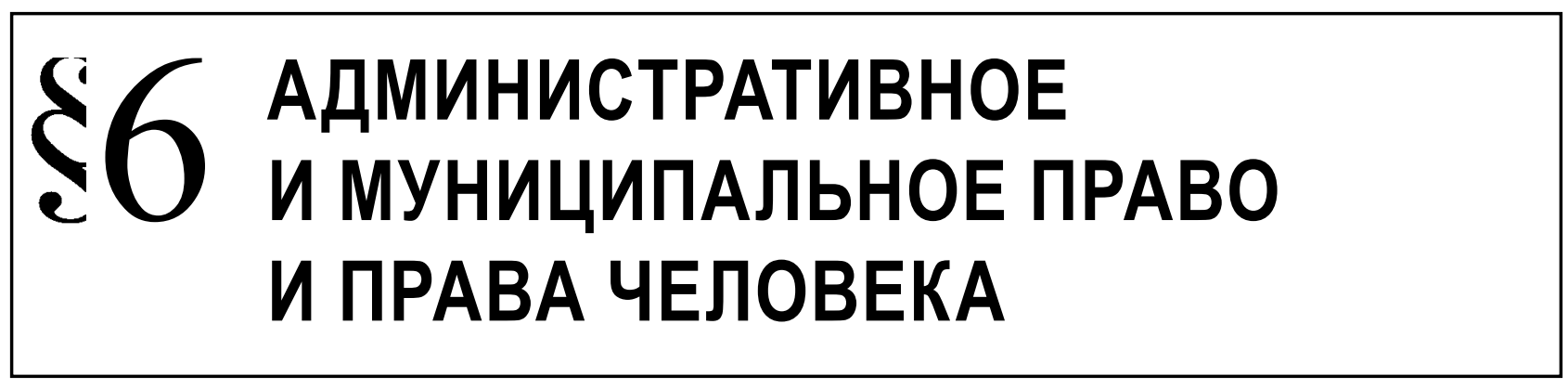

Адмиралова И.А.

\title{
ТЕОРИЯ И МЕТОДОЛОГИЯ АДМИНИСТРАТИВНОЙ ДЕЯТЕЛЬНОСТИ ПОЛИЦИИ В СФЕРЕ ОБЕСПЕЧЕНИЯ ПРАВ И СВОБОД ГРАЖДАН
}

\begin{abstract}
Аннотация: Исследуются проблемы обеспечения прав и свобод граждан через административно-правовой механизм деятельности полиции, обращается внимание на конструктивные составляющие методологического подхода обеспечения прав и свобод граждан в деятельности поличии. В статье рассматриваются основные этапы развития учения, связанного с обеспечением прав и свобод человека и гражданина в деятельности органов внутренних дел (полиции), на основании проведенного исследования предлагаются изменения в действующее законодательство с учетом которых может качественно улучшиться работа органов государственной власти и управления, а также органов внутренних дел (полиции). Методологическую основу статьи составили современные достижения теории познания. В процессе исследования применялись общефилософский, теоретический, диалектика, системный метод, анализ, синтез, аналогия, дедукция, наблюдение, моделирование), традиционно правовые методы (формально-логический), а также методы, ис-пользуемые в конкретно-сочиологических исследованиях (статистические, экспертные оценки и др.). Учитывая наработки, можно проследить генезис развития учения, связанного с обеспечением прав и свобод граждан в административной деятельности органов внутренних дел (полиции). Рассмотрение некоторых проблем обеспечения прав и свобод граждан в административной деятельности органов внутренних дел дает возможность обратить внимание на тот факт, что административно-правовой инструментарий не может быть эффрективно использован без применения межотраслевого подхода, $в$ особенности, если это касается рассматриваемой проблемы.
\end{abstract}

Ключевые слова: методалогия, права, свободы, поличия, обеспечение, охрана, защита, стандарт, полицейский, средство.

Л огика анализа содержания административной деятельности полиции по обеспечению прав и свобод граждан предполагает раскрытие концепции и методологии соответствующего исследования. Как утверждал Д.А. Керимов «...методология выступает в качестве путеводной нити, руководства исследовательского процесса. Методологическое мышление призвано превращать объективное в субъективное, познание в познанное, а реальные объекты, явления, а также процессы в их осознанные образы» ${ }^{1}$.

Именно поэтому методологический подход к

1 См.: Керимов Д.А. Методология права. Предмет, функции, проблемы философии права. - М., 2009. - С. 9. раскрытию обозначенной проблемы представляется весьма обоснованным. Обеспечение прав и свобод граждан - это проблема, которая решается на протяжении многих веков развития человеческой цивилизации, и только к концу XX в. некоторым государствам удалось в определенной мере приблизиться к ее решению. Однако отметим, что проблема обеспечения прав и свобод граждан в деятельности российской полиции весьма молода. Представляется возможным также заметить, что серьезные исследования обозначенной проблемы начали проводиться лишь в середине 80-х годов XX в. Обусловлено это тем, что вопросы обеспечения прав и свобод граждан в деятельности публичной администрации стали актуальными лишь после принятия 
целого ряда международно-правовых актов, посвященных правам человека и гражданина. Такие акты, в частности, были приняты как на международноправовом, так и на европейском уровне. «Достоинство и права человека, их генезис, нравственнофилософское обоснование и юридическая природа, глобальные угрозы их существованию и средства их преодоления, сравнительный анализ уровня их обеспечения, способы их имплементации в разных государствах, а также универсальный механизм их гарантий - таковы их основные проблемы, которые имеют место в настоящее время» 2 .

В советский период истории нашего государства содержательных исследований, посвященных непосредственно правам и свободам человека и гражданина практически не проводилось, научному анализу в теоретическом и конституционноправовом аспекте подвергалось лишь правовое положение личности. Подобное положение вещей было связано с целым рядом обстоятельств, как правило, субъективного порядка. Неслучаен был тезис Ф.М. Рудинского о том, что «... наша юриспруденция фактически отрицала глобальную значимость всеобщей концепции прав человека, которая рассматривалась в качестве «абстрактной» или «буржуазной». А зафиксированные в международных актах права человека в теории и на практике отождествлялись с урезанными правами советского гражданина, в результате чего принижалось значение гражданских прав и недооценивалось право на жизнь как первейшее право человека» ${ }^{3}$. Обеспечение прав и свобод граждан в административной деятельности органов внутренних дел исключением не являлось.

Как мы уже отмечали, ранее, проблема обеспечение прав и свобод граждан в деятельности органов внутренних дел начала привлекать к себе внимание ученых лишь в середине 80-х годов XX в. Именно в этот период Г.В. Мальцев отмечал, что «...прогресс в исследовании прав личности был настолько очевиден, что не было надобности доказывать это утверждение» ${ }^{4}$.

Именно в обозначенный период развития юридической науки на основе общетеоретических

\footnotetext{
2 См.: Рудинский Ф.М. Вузовская программа «История, теория и практика прав человека» (к итогам дискуссии) // Государство и право. - 1995. - № 2. - С. 31.

3 Там же. - С. 22.

4 См.: Мальцев Г.В. Права личности: юридическая норма и социальная действительность // Конституция СССР и правовое положение личности. - М., 1979. - С. 48.
}

исследований анализируется правоприменительная деятельность органов внутренних дел в соответствующем направлении. В изучении проблемы обеспечении прав и свобод граждан использовался различный инструментарий, а также различная методология. При изучении проблем обеспечения прав и свобод граждан в административной деятельности органов внутренних дел традиционно использовались диалектические и частно-научные методы. Еще в XIX в. И.Т. Тарасов подчеркнул то обстоятельство, что «...в виду чрезвычайной сложности явлений, исследуемых в науки полицейского права, метод индуктивно-дедуктивный является единственно возможным в применении к этой науке» 5 .

В свое время, И.С. Самощенко и В.М. Сырых раскрывая методологию правоведения, отмечали, что метод диалектики являлся всеобщим методом научного познания, в связи с чем он использовался для полноты, всесторонности, объективности познания. В свою очередь «частно-научные методы необходимы для осуществления сравнительного правоведения, применения системно-структурного подхода, моделирования, а также историко-правового анализа и др.». ${ }^{6}$

Учитывая общетеоретические и методологические наработки, можно проследить генезис развития учения, связанного с обеспечением прав и свобод граждан в административной деятельности органов внутренних дел (полиции). Так, рассмотрение некоторых проблем обеспечения прав и свобод граждан в административной деятельности органов внутренних дел дает возможность обратить внимание на тот факт, что административно-правовой инструментарий не может быть эффективно использован без применения межотраслевого подхода, в особенности, если это касается рассматриваемой проблемы.

Таким образом, представляется неслучайно использование при проведении административноправовых исследований обозначенной проблемы наработок, которые имелись в науки конституционного права. Такая тенденция вполне обоснована. Связано это с тем, что Конституция любого государства закрепляет основные и неотъемлемые права человека и гражданина, которые, так

\footnotetext{
См.: Тарасов И.Т. Очерк науки полицейского права. - М., 1897. - С. 8.

6 См.: Самощенко И.С., Сырых В.М. К методологии советского правоведения // Советское государство и право. 1973. - № 6. - С. 29.
} 
или иначе, обеспечиваются государством в лице его компетентных и правоохранительных органов. Именно такой подход наиболее отчетливо виден в 80-е годы XX в. - в этот период времени проблема обеспечения прав и свобод человека и гражданина зазвучала в исследованиях по административному праву. В качестве примера можно привести ряд работ, которые посвящены обозначенному вопросу. Так, обращает на себя внимание исследование, проведенное А.И. Колташевым, в котором на междисциплинарной основе анализируется принцип единства прав и обязанностей граждан, а также участие в его реализации органов внутренних дел ${ }^{7}$.

В этой работе, справедливо, на наш взгляд, отмечается, что реализация большинства прав граждан не требует правоприменительной деятельности органов внутренних дел, однако реализация специальных прав и обязанностей со стороны гражданина требует контроля со стороны органов внутренних дел, это, прежде всего, относится к тем правам и обязанностям, которые реализуются гражданами в сфере охраны общественного порядка. На то обстоятельство, что статус граждан в сфере общественного порядка имеет определенную специфику, обращалось внимание в работах Н.И. Буденко ${ }^{8}$ И.А. Ивановой ${ }^{9}$, Л.М. Рябцева ${ }^{10}$, Н.И. Раздымалиной ${ }^{11}$.

Если обобщить результаты обозначенных работ, то в этих исследованиях анализируются субъективные права и юридические обязанности граждан в общественных местах, а также особенности правового положения граждан в сфере охраны общественно порядка. В проведенных исследованиях также акцентировалось внимание на использование правоохранительных, административно-правовых средств обеспечения правового положения

\footnotetext{
7 См.: Колташов А.И. Конституционный принцип единства прав и обязанностей граждан СССР и участие в обеспечении его реализации органов внутренних дел: Автореф. дис. ... канд юрид наук. - М., 1985.

8 Буденко Н.И. Административно-правовое положение граждан в сфере общественного порядка: Дис. ... канд. юрид. наук. - М., 1986.

9 Иванова И.А. Административно-правовая охрана субъективных прав советских граждан в сфере общественного порядка: Дис. ... канд. юрид. наук. - М., 1986.

10 Рябцев Л.М. Административно-правовая деятельность советской милиции в защите личных прав граждан (по материалам Белорусской ССР): Автореф ... канд. юрид. наук. - М., 1990.

11 Раздымалина Н.И. Механизм реализации гарантий прав и свобод граждан в сфере охраны общественного порядка: Автореф ... канд. юрид. наук. - М., 1991.
}

граждан в специфической сфере жизнедеятельности людей, со стороны различных органов государственного управления, в том числе и органов внутренних дел. Все эти работы по-своему развивали общетеоретическое и конституционно-правовое учение о статусе личности в сфере государственного управления. В них, а также в некоторых других работах доказывалась необходимость и важность деятельности органов внутренних дел в деле обеспечения правового статуса личности.

По мнению, например, К.Б. Толкачев, «основанная на строгом соблюдении режима законности деятельность органов внутренних дел является необходимым условием правомерного, беспрепятствованного пользования гражданами своими конституционными правами» ${ }^{12}$.

Также весьма серьезными были усилия в исследовании административно-процессуального положения граждан в производствах, которые осуществлялись в органах внутренних дел. В частности, весьма содержательно было исследовано право лица, в отношении которого осуществлялось производство по делу об административном правонарушении. В числе принципов соответствующего производства проявился и принцип охраны прав и законных интересов граждан. С.И. Котюргиным, применительно к административно-процессуальной деятельности органов внутренних дел была разработана система прав и законных интересов граждан. Важнейшими принципами процессуальной деятельности в этом направлении стали являться такие принципы, как доказанность обвинения; предоставление привлекаемому к ответственности лицу права защиту (представление доказательств, ознакомление с материалами дела, обжалования принятых решений в судебном и административном порядке и др. $)^{13}$.

Все это говорит о том, что обеспечение прав и свобод граждан стало одной из основных задач органов внутренних дел. За соблюдением прав и свобод граждан в административной деятельности органов внутренних дел, более предметно, начал осуществляться прокурорский надзор, совершенствовались формы общественного контроля, а также развивались различные виды контрольной деятельности

\footnotetext{
12 Толкачев К.Б. Место органов внутренних дел в механизме реализации личных конституционных прав и свобод граждан: Автореф ... канд. юрид. наук. - М., 1984.

13 См.: Котюргин С.И. Понятие, принципы и формы административно-процессуальной деятельности милиции. Омск, 1973. - С. 56.
} 
со стороны разнообразных органов государственного управления, в том числе - вышестоящих органов внутренних дел. Соблюдение прав и свобод граждан постепенно превращалось в приоритетное направление деятельности органов внутренних дел.

В 90-е годы XX в. интерес к проблеме прав и свобод граждан был вызван принятием Конституции России, которая качественно иным образом определила права граждан, особенно те из них, обеспечение которых напрямую связано с деятельностью органов внутренних дел (полиции). Закрепленные в Конституции права и свободы касаются как материального, так и процессуального аспекта деятельности полиции. Некоторые из прав граждан реализуются гражданином непосредственно, реализация других предполагает соблюдение целого ряда административных процедур.

Согласно Конституции, права граждан условно подразделяются на личные (гражданские) права, права социально-экономического характера, права политического характера и так далее. В пределах своей компетенции полиция обеспечивает возможность реализации гражданином всех без исключения предоставленных ему прав и свобод. В научной литературе вышеизложенное конкретизируется. Например, Ю.Г. Арзамасов указывает на то, что в нормотворческой деятельности МВД России реализуются личные права, политические права, а также социально-экономические права человека и гражданина ${ }^{14}$. В целом, такая классификация, без формальной конкретизации, включает практические все без исключения права, которые определены за гражданином Конституцией Российской Федерации.

Подтверждением того, что в 90 -е годы XX в. начала кардинально переосмысливаться деятельность органов внутренних дел в вопросах обеспечения прав и свобод граждан, может являться симпозиум, посвященный теме: «Права человека и статус правоохранительных органов», который был проведен в Санкт-Петербургском юридическом институте МВД России в 1994 г. ${ }^{15}$ В материалах этого научного форума констатировалась необходимость практической реализации конституционных норм в деятельности правоохранительных органов в це-

14 См.: Арзамасов Ю.Г. Нормотворческая деятельность МВД России в механизме реализации прав человека и гражданина. - М., 2000. - С. 138.

15 См.: Права человека и статус правоохранительных органов (Материалы симпозиума в Санкт-Петербургском юридическом институте МВД России) // Государство и право. -1994. - № 11. - С. 81. лом, и органов внутренних дел, в частности. Кроме того, указывалось на необходимость учета международных стандартов обеспечения разнообразных прав и свобод человека и гражданина в полицейской деятельности. Материалы обозначенного научного форума впоследствии получили свое отражение в научных исследованиях, посвященных деятельности органов внутренних дел в соответствующей сфере. Знаковыми событиями в развитии учения о деятельности органов внутренних дел в сфере обеспечения прав и свобод человека и гражданина явились фундаментальные работы И.Ш. Килясханова ${ }^{16}$ и И.В. Ростовщикова ${ }^{17}$.

Перечисленные исследования были проведены в один и тот же период времени, в каждом из них своя методология и концепция исследования обеспечения прав и свобод человека и гражданина. Однако, несмотря на это, рассматриваемой проблеме дан весьма содержательный теоретический и административно-правовой анализ. В приведенных исследованиях анализируются формы и методы деятельности органов внутренних дел, которые традиционно использовались в деле обеспечения прав и свобод граждан. Особое внимание обращается на контрольно-надзорную, разрешительную, а также юрисдикционную деятельность органов внутренних дел. Такой подход во многом обусловлен тем, что именно в этих направлениях полицейской деятельности наиболее часто нарушаются права и свободы граждан, кроме того, указанные направления деятельности органов внутренних дел вовлекают большое количество граждан, а также представителей хозяйствующих субъектов. В связи с этим, формы и методы работы органов внутренних дел в соответствующем направлении административной деятельности полиции всегда нуждались в своей оптимизации.

Практически в тот же период времени проводились научные исследования, связанные с обеспечением прав и свобод человека и гражданина в общегуманитарном аспекте. В частности, переиздается ряд монографий, посвященных правовому статусу личности ${ }^{18}$, публикуется фундаментальная

\footnotetext{
16 Килясханов И.Ш. Проблемы обеспечения прав и свобод граждан в сфере административной деятельности милиции: Дис. ... д-ра юрид. наук. - М., 1997.

17 Ростовщиков И.В. Обеспечение и защита прав и свобод личности: вопросы теории и практика органов внутренних дел: Автореф. дис. ... д-ра юрид. наук. - М., 1997.

18 Воеводин Л.Д. Юридический статус личности в России. - M., 1997.
} 
работа «Общая теория прав человека» ${ }^{19}$, в данной работе, по сути, был обобщен научный материал по вопросу обеспечения прав человека и гражданина, учтена практика конституционнного правосудия, а также международный и европейский опыт обеспечения прав и свобод личности.

По мере развития юридической теории, развивается и правоприменительная практика, создаются новые государственно-правовые институты, в компетенции которых сосредотачиваются средства обеспечения прав и свобод человека и гражданина. В частности, в научной литературе весьма содержательно обосновывается необходимость формирования института административной юстиции, вносятся предложения по совершенствованию форм и методов работы Уполномоченного по права человека, деятельность которого и в настоящее время может внести весьма существенный вклад в решение проблемы обеспечения прав и свобод граждан в административной деятельности полиции. Существенным вкладом в развитие учения, касающегося обеспечения прав и свобод граждан явилось издание сборника научных трудов «Права человека и политическое реформирование», в котором ученые Института государства и права Российской академии наук весьма обстоятельно раскрыли принципиальные вопросы рассматриваемой проблемы ${ }^{20}$.

Соответствующие теоретические наработки сохраняют свою актуальность и весьма существенно востребованы, в том числе и для обеспечения прав и свобод человека и гражданина в административной деятельности полиции в настоящее время. Обусловлено это тем, что в них содержится серьезный гуманистический и научный потенциал. Как отмечал B.C. Нерсесянц «...согласно новым преставлениям о ценностях права и правовой идеологии российской Конституции, права и свободы человека и гражданина имеют общерегулятивное, императивно-правовое значение и выступают как основной критерий для определения правового качества закона и организации деятельности всех ветвей и звеньев государственной власти и государства в целом» ${ }^{21}$.

19 Общая теория прав человека / Рук авт. кол. Е.А. Лукашева. - М., 1996.

20 Права человека и политическое реформирование (юридические, этические, социально-психологические аспекты) / Отв. ред. Е.А. Лукашева. - М., 1997.

21 См.: Нерсесянц В.С. Права и свободы человека как фактов общеевропейского сотрудничества и интеграции // Права человека и политическое реформирование (юридические, этические, социально-психологические аспекты). - М., 1997. - С. 37.
Представляется правильным согласиться с тем, что мерилом качества закона может являться то, насколько принятый закон в ходе своей реализации дает возможность человеку использовать предоставленное ему право в той или иной сфере государственного управления или своей жизнедеятельности. Следует оговориться, что каждый гражданин, конечно же, сразу не может реализовать весь комплекс прав, которые ему предоставлены Конституцией за исключением, разумеется, тех которые являются его личными неотчуждаемыми правами. В развитие конституционного закрепления прав и свобод граждан принят целый ряд федеральных законов, в которых определяется механизм реализации многих положений Конституции. Однако, несмотря на прямое действие Конституции, а также ее высшую юридическую силу, целый ряд прав, которые предоставлены гражданину, не может быть им реализован в абсолютном порядке. Так, граждане Российской Федерации имеют право собираться мирно, без оружия, проводить собрания, митинги и демонстрации, шествия и пикетирование. Но реализация данного права упирается в Федеральный закон от 19 июня 2004 г. «0 собраниях, митингах, демонстрациях, шествиях и пикетированиях» ${ }^{22}$.

Объективным является право каждого, кто законно находится на территории Российской Федерации, свободно передвигаться, выбирать место пребывания и жительства. Кроме того, каждый может свободно выезжать за пределы Российской Федерации. Механизм реализации данного права определяется в Законе РФ от 25 июня 1993 г. «0 праве граждан Российской Федерации на свободу передвижения, выбор места пребывания и жительства в пределах Российской Федерации» ${ }^{23}$, Федеральным законом от 15 августа 1996 г. «0 порядке выезда из Российской Федерации и въезда в Российскую Федерацию» ${ }^{24}$.

Примерно такой же механизм определяется и для реализации практически каждого конституционного права гражданина. Однако, несмотря на, казалось бы, правильный правовой механизм реализации прав и свобод человека и гражданина, на практике практически каждый сталкивается с большим количеством, как представляется,

22 Собрание законодательства РФ. - 2004. - № 25. - Ст. 2485.
23 Ведомости СНД и ВС РФ. - 1993. - № 32. - Ст. 1227.
24
Собрание законодательства РФ. - 1996. - № 34. - Ст. 4029. 
необоснованно установленных бюрократических процедур, в ходе которых происходит нарушение его прав и законных интересов, в связи с чем качество закона лишается своего правового, а также конституционного смысла. Качество нормативноправовой регламентации общественных отношений, к сожалению, и в сфере внутренних дел также оставляет желать лучшего. Несмотря на большое количество законов, вполне очевидна тенденция снижения уровня обеспечения прав и свобод человека и гражданина практически во всех сферах государственного управления. Приходится признать, что существенная работа, которая проведена за последние двадцать лет по исследованию прав и свобод человека и гражданина, а также интеграция российской правовой системы в европейское правовое пространство, отчасти нивелирована содержательной частью действующих федеральных законов, а также бюрократической процедурой их реализации.

В настоящее время необходимо кардинальное переосмысление административной деятельности, в том числе и осуществляемой полицией, следует переориентировать ее на более высокое качественное обслуживание интересов человека и гражданина, преодоление отчуждения должностных лиц органов государственной власти и управления от насущных проблем граждан. Конечно, нельзя принять закон, создать правоохранительную систему, которая будет способствовать снижению цинизма, бездушия, равнодушия, которые имеют место во всех, без исключения, органах государственной власти и управления. В настоящее время, несмотря на имеющие место административные регламенты, гражданин так и не может с минимальной затратой времени, а также сил получить необходимый ему документ, справку, свидетельство, разрешение и т.п.

Все это, в конечном счете, снижает доверие к государственным институтам, провоцирует граждан к изысканию возможности подкупа соответствующих должностных лиц, а также зачастую, поиска нового места для своего жительства или работы в европейских или иных странах. Для исправления сложившейся ситуации, как никогда необходимо кардинальное переосмысление системы государственного управления, повышение качества государственных услуг посредством формирования персональной ответственности всех, без исключения, должностных лиц. Вполне актуальным сегодня выглядит предложение А.И. Столмакова о том, что «...одновременно с пер- сональной ответственностью должностных лиц надо всемерно развивать ответственность коллективных субъектов права» 25.

На повестке дня развитие добросовестной конкуренции на рынке государственных услуг, формирование института «позитивного административного молчания» ${ }^{26}$, а также формирование правовых механизмов зависимости должностного лица от насущных требований отдельно взятого гражданина.

Конечно, ненужно абсолютизировать права и свободы человека и гражданина: в какой бы сфере они не реализовывались, человек в силу реальной объективности всегда упирается в определенные правовые и социальные ограничения. В современном обществе реализация прав и свобод не может быть абсолютной, поскольку это неизбежно приведет к нарушению прав других людей, будет представлять угрозу государственным и общественным интересам. В этом направлении К. Экштайн верно подметил, что «... основные права и свободы образуют важный элемент системы, регламентирующей совместную жизнь людей, кроме того права и свободы - это часть правовой системы» ${ }^{27}$. Права и свободы граждан определяют определенную взаимосвязь между различными людьми, которые пребывают в данный момент в соответствующей социальной среде.

Также логичным выглядит тезис авторов учебного пособия «Права и свободы человека и гражданина» о том, что «...не может быть абсолютной свободы государства, так и не может быть безграничной свободы каждого: неограниченная свобода приводит к неограниченной деспотии сильнейших и бессовестнейших. Однако свобода дается каждому в равной мере, в том числе и слабому и не имеющему средств к существованию. Это равное право каждого человека должно быть защищено государством, тем более, что именно государство устанавливает предел

\footnotetext{
25 См.: Столмаков А.И. Административно-правовые и судебные методы охраны субъективных прав граждан СССР: Автореф. дис. .... канд. юрид наук. - М., 1971. - С. 13.

26 Суть данного института должна заключаться в том, что если гражданин подал соответствующее заявление и не получил в установленный нормативно срок ответа решение считается принятым в его пользу, в связи с чем он может пользоваться соответствующем правом, но при этом он должен иметь подтверждение своего обращения.

27 См.: Экштайн К. Основные права и свободы. - М., 2004. - C. 11.
} 
свободы каждого и наказывает за злоупотребления свободой» ${ }^{28}$.

Приведенный тезис имеет самое непосредственное отношение и к деятельности полиции, которая, как уже ранее отмечалось, в пределах своей компетенции обеспечивает права и свободы человека и гражданина теми средствами, которых нет у других органов государственной власти и управления. Анализ компетенции полиции в этом аспекте показывает, что обеспечение прав и свобод граждан в административно-правовой сфере воздействия достигается посредством контрольнонадзорной деятельности, которая реализуется в самых разнообразных формах и с помощью различных методов. В процессе осуществления контрольно-надзорной деятельности проводится профилактическая работа, которая внешне практически не заметна, она, как правило, не дает объективных качественно-количественных показателей, но зато она позволяет сформировать в общественных местах обстановку спокойствия и социального благополучия. При такой ситуации люди могут чувствовать собственную и имущественную безопасность, это позволяет им реализовать свои культурные права, право на отдых в парках, скверах и иных местах массового пребывания и отдыха людей. Различными профилактическими средствами обеспечивается большое количество прав и свобод человека и гражданина в социально-культурной, социально-экономической и имущественной сфере жизнедеятельности людей.

Профилактическая деятельность полиции обеспечивает не только обстановку социального благополучия, она также помогает выявлять различного рода административные правонарушения или иные отклонения от соблюдения правовых и социальных норм. Таким образом, в ходе профилактической работы сотрудники полиции вынуждены применять меры административного принуждения как специального, так и юрисдикционного характера. Такие меры уже по иному обеспечивают права и свободы гражданина, а именно - они ограждают его от противоправного поведения других людей, создают благоприятное социальное пространство. При этом не нужно забывать и другого обстоятельства: сотрудник полиции, применяя меры административного воздействия, должен учитывать как правовой,

28 См.: Лейбо Ю.И., Толстопятенко Г.П., Экштайн К.А. Права и свободы человека и гражданина: научно-практический комментарий к Главе 2 Конституции Российской Федерации. - М., 2000. - С. 20. так и социально-гуманистический аспект при его реализации, а также элементарную целесообразность, в частности, при осуществлении доставления или административного задержания гражданина, совершившего административное правонарушение. Далее поясним вышесказанное.

Вполне понятно, что нельзя появляться в общественных местах в состоянии алкогольного опьянения, которое оскорбляет человеческое достоинство. Такое состояние, а также поведение человека, несомненно, нарушает права и свободы других людей, кроме того, человек, находясь в состоянии алкогольного опьянения, создает рискованную ситуацию для себя лично. Человек в таком состоянии может нарушить работу общественного транспорта, быть потерпевшим от имущественного посягательства и др.

В большинстве случаев сотрудник полиции обязан пресечь такое поведение человека и, в установленном процессуальном порядке, доставить его в территориальный отдел полиции или иное помещения для установления его личности, составления протокола об административном правонарушении и др. Однако вышесказанное будет правильно лишь в отдельных случаях.

В другом случае, сотрудник полиции, подойдя к гражданину находящемуся в состоянии алкогольного опьянения, увидев, что человек ориентируется в пространстве, целенаправленно следует домой, не создает никаких угроз общественному порядку и безопасности, может ограничиться профилактической беседой. И в силу малозначительности административного правонарушения, освободить соответствующего гражданина от официального административного принуждения, и, в частности, от административной ответственности. Как представляется, такой вариант поведения сотрудника полиции в наибольшей степени будет целесообразным, отвечать интересам обеспечения прав и свобод человек и гражданина, а также способствовать повышению авторитета полиции в глазах населения нашей страны.

В иных сферах социальной действительности полиция также обеспечивает права и свободы граждан тем арсеналом административно-правовых средств, которые находятся в ее распоряжении как непосредственно, так и во взаимодействии с другими органами государственной власти и управления, а также институтами гражданского общества. Однако надо признать, что имеющиеся регламенты взаимодействия, должной концентрации усилий взаимодействующих структур в деле обеспечения прав 
и свобод человека и гражданина пока, к сожалению, не дали. Вполне очевидно, что конституционный принцип, связанный с приоритетом прав и свобод человека и гражданина, которые ко всему прочему еще должны являться смыслом и содержанием деятельности органов государственной власти, пока так как нужно людям, не работает.

Несмотря на реальную картину, связанную с обеспечением прав и свобод граждан, теоретические исследования в этом направлении продолжаются, и эту тенденцию следует всячески поддерживать. Вполне очевидно, что для реального действия конституционных прав и свобод человека и гражданина, в том числе реализуемых в сфере внутренних дел, необходимо реальное действие также и конституционных гарантий, которых, как показывает изучение основного закона, в действующей Конституции России пока явно не достает. Основным гарантом прав и свобод граждан выступает Президент России, однако только лишь его усилий в рассматриваемой сфере явно не достаточно. Необходимо подчеркнуть, что права и свободы граждан будут реально работать, если к этому будут приложены усилия не только органов государственной власти и управления, а также соответствующая деятельность и самих граждан. В этой связи Е.Н. Хазов верно отмечает, что «...механизм реализации зависит от правовой культуры носителей прав и обязанностей, в связи с чем каждый человек и гражданин должен знать свои права, свободы и обязанности, а также правильно ими пользоваться» ${ }^{29}$.

Действительно, от гражданина в деле реализации им своих прав и свобод многое зависит, однако не следует от обычного человека требовать сверхусилий, ставить перед ним задачу обращаться в суд за защитой своих прав, требовать от него действий, связанных с защитой его прав в европейских правозащитных институтах. Такой вариант защиты под силу лишь весьма обеспеченным людям, каковых в нашей стране не так и много. Государство, в лице своих органов власти и управления должно пересмотреть качество своей работы в деле обеспечения прав и свобод граждан, а также создать максимально комфортные и удобные условия для их реализации. В настоящее время можно наблюдать развитие информационных технологий в деле предоставления самых разнообразных государственных услуг, в том числе, и в сфере внутренних дел. Такой подход отвечает духу времени, дает возможность человеку,

29 См.: Хазов Е.Н. Конституционные гарантии прав и свобод человека и гражданина в России. - М., 2014. - С. 312. не выходя из дома получить необходимую ему государственную услугу, а также информацию и т.п. Однако в этом механизме, несмотря на его современность, а также определенную востребованность, есть и некоторые недоработки, а именно: им может воспользоваться всего лишь некоторое количество, весьма «продвинутых» в современных информационных технологиях людей. В связи, с этим реализация самых разнообразных прав граждан посредством современных информационных технологий в настоящее время малоэффективна.

В вопросах реализации прав и свобод граждан в сфере деятельности полиции, по нашему мнению, необходимо использовать зарубежный опыт лишь в том аспекте, в котором он может быть адаптирован и использован в нашей стране. В частности, весьма позитивным видится формирование небольших по своему штату отделов полиции, в которых будут нести службу только участковые уполномоченные полиции и сотрудники уголовного розыска. Эти отделения полиции могут обслуживать небольшие по площади и численности населения районы в крупных городах. Создание таких отделений позволит своевременно реагировать на различные правонарушения, которые связаны с посягательством на имущество граждан, предупреждать бытовые конфликты, а также противоречия, возникающие на межнациональной и экстремистской почве. Представляется также важным формирование различного рода бюро жалоб. В эти структуры сможет обратиться гражданин, право которого в том или ином аспекте нарушено. Видеться целесообразным и формирование правового механизма информирования людей о принятой мере воздействия в отношении виновного должностного лица. В месте работы чиновника, действия которого признаны незаконными или необоснованными, возможно следует размещать информационные стенды, на которых помещать данные о качестве работы соответствующего должностного лица с указанием, разумеется, не только положительной информации.

В завершении рассмотрения проблем обеспечения прав и свобод граждан в методологическом аспекте, представляется возможным отметить, что решение ряда проблем в этом направлении позволит государству сделать весьма существенные шаги в деле своего социально-экономического и политического развития, а также повысить уровень доверия к государственным институтам, в том числе и полиции, со стороны значительной части социально активных и прогрессивно мыслящих людей. 


\section{Библиография:}

1. Арзамасов Ю.Г. Нормотворческая деятельность МВД России в меха-низме реализации прав человека и гражданина. - М., 2000.

2. Керимов Д.А. Методология права. Предмет, функции, проблемы фи-лософии права. - М., 2009. Лейбо Ю.И., Толстопятенко Г.П., Экштайн К.А. Права и свободы человека и гражданина: научно-практический комментарий к Главе 2 Конституции Российской Федерации. - М., 2000.

3. Мальцев Г.В. Права личности: юридическая норма и социальная дей-ствительность // Конституция СССР и правовое положение личности. - М., 1979.

4. Рудинский Ф.М. Вузовская программа «История, теория и практика прав человека» (к итогам дискуссии) // Государство и право. - 1995. - № 2.

5. Столмаков А.И. Административно-правовые и судебные методы ох-раны субъективных прав граждан СССР: Автореф. дис. .... канд. юрид наук. - М., 1971. - С. 13.

6. Хазов Е.Н. Конституционные гарантии прав и свобод человека и гра-жданина в России. - М., 2014. - С. 312.

7. Экштайн К. Основные права и свободы. - М., 2004.

8. Адмиралова И.А. Административная деятельность полиции и обеспечения прав и свобод граждан // Административное и муниципальное право. - 2014. - 6. - С. 550 - 558. DOI: 10.7256/1999-2807.2014.6.12075.

9. Костенников М.В. Принцип законности и его реализация в деятельности сотрудников органов внутренних дел // Полицейская деятельность. - 2014. - 3. - С. 301 - 309. DOI: 10.7256/2222-1964.2014.3.12361.

10. Трегубова Е.В. Административные запреты в сфере осуществления полицейской деятельности // NB: Российское полицейское право. - 2013. - 1. - С. 25 - 44. DOI: 10.7256/2306-4218.2013.1.718. URL: http://www.e-notabene. $\mathrm{ru} / \mathrm{pm} /$ article_718.html

11. Куракин А.В., Костенников М.В. Принципы организации и деятельности российской полиции // NB: Российское полицейское право. - 2013. - 2. - C. 22 - 49. DOI: 10.7256/2306-4218.2013.2.799. URL: http://www.e-notabene.ru/ pm/article_799.html

12. Адмиралова И.А. Общественный порядок и права граждан // Полицейская деятельность. - 2014. - 3. - С. 251 257. DOI: $10.7256 / 2222-1964.2014 .3 .12362$.

13. Адмиралова И.А. Статус граждан как субъектов административного права и роль полиции в его обеспечении // Административное и муниципальное право. - 2014. - 5. - С. 430 - 439. DOI: 10.7256/1999-2807.2014.5.11729.

14. Адмиралова И.А., Кареева-Попелковская К.А. Меры административного пресечения и механизм их реализации полицией в целях обеспечения прав и свобод граждан // Административное и муниципальное право. - 2014. 4. - C. 351 - 359. DOI: 10.7256/1999-2807.2014.4.11434.

\section{References (transliterated):}

1. Arzamasov Yu.G. Normotvorcheskaya deyatel'nost' MVD Rossii v mekha-nizme realizatsii prav cheloveka i grazhdanina. - M., 2000.

2. Kerimov D.A. Metodologiya prava. Predmet, funktsii, problemy fi-losofii prava. - M., 2009. Leibo Yu.I., Tolstopyatenko G.P., Ekshtain K.A. Prava i svobody cheloveka i grazhdanina: nauchno-prakticheskii kommentarii k Glave 2 Konstitutsii Rossiiskoi Federatsii. - M., 2000.

3. Mal'tsev G.V. Prava lichnosti: yuridicheskaya norma i sotsial'naya dei-stvitel'nost' // Konstitutsiya SSSR i pravovoe polozhenie lichnosti. - M., 1979.

4. Rudinskii F.M. Vuzovskaya programma «Istoriya, teoriya i praktika prav cheloveka» (k itogam diskussii) // Gosudarstvo i pravo. - 1995. - № 2.

5. Stolmakov A.I. Administrativno-pravovye i sudebnye metody okh-rany sub"ektivnykh prav grazhdan SSSR: Avtoref. dis. .... kand. yurid nauk. - M., 1971. - S. 13.

6. Khazov E.N. Konstitutsionnye garantii prav i svobod cheloveka i gra-zhdanina v Rossii. - M., 2014. - S. 312.

7. Ekshtain K. Osnovnye prava i svobody. - M., 2004.

8. Admiralova I.A. Administrativnaya deyatel'nost' politsii i obespecheniya prav i svobod grazhdan // Administrativnoe i munitsipal'noe pravo. - 2014. - 6. - C. 550 - 558. DOI: 10.7256/1999-2807.2014.6.12075.

9. Kostennikov M.V. Printsip zakonnosti i ego realizatsiya v deyatel'nosti sotrudnikov organov vnutrennikh del // Politseiskaya deyatel'nost'. - 2014. - 3. - C. 301 - 309. DOI: 10.7256/2222-1964.2014.3.12361.

10. Tregubova E.V. Administrativnye zaprety v sfere osushchestvleniya politseiskoi deyatel'nosti // NB: Rossiiskoe politseiskoe pravo. - 2013. - 1. - C. 25 - 44. DOI: 10.7256/2306-4218.2013.1.718. URL: http://www.e-notabene.ru/pm/ article_718.html

11. Kurakin A.V., Kostennikov M.V. Printsipy organizatsii i deyatel'nosti rossiiskoi politsii // NB: Rossiiskoe politseiskoe pravo. 2013. - 2. - C. 22 - 49. DOI: 10.7256/2306-4218.2013.2.799. URL: http://www.e-notabene.ru/pm/article_799.html

12. Admiralova I.A. Obshchestvennyi poryadok i prava grazhdan // Politseiskaya deyatel'nost'. - 2014. - 3. - C. 251 - 257. DOI: 10.7256/2222-1964.2014.3.12362.

13. Admiralova I.A. Status grazhdan kak sub"ektov administrativnogo prava i rol' politsii v ego obespechenii // Administrativnoe i munitsipal'noe pravo. - 2014. - 5. - C. 430 - 439. DOI: 10.7256/1999-2807.2014.5.11729.

14. Admiralova I.A., Kareeva-Popelkovskaya K.A. Mery administrativnogo presecheniya i mekhanizm ikh realizatsii politsiei $\mathrm{v}$ tselyakh obespecheniya prav i svobod grazhdan // Administrativnoe i munitsipal'noe pravo. - 2014. - 4. - C. 351 - 359. DOI: $10.7256 / 1999-2807.2014 .4 .11434$. 